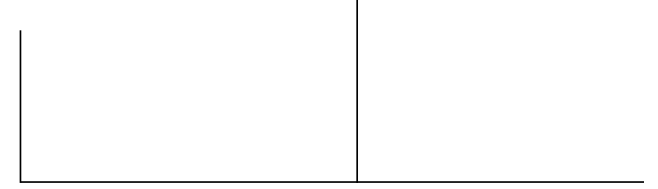

Rev. Latinoam. Psicopat. Fund., IV, 4, 158-161

Presença e implicações da noção de escrita na obra de Jacques Lacan

Ana Maria Netto Machado

Ijuí: Ed. Unijui, 1998

\title{
Da escrita invisível à letra muda e visível
}

\section{Vera Lúcia Colucci}

Considerada como mero suporte para a expressão do pensamento, tal como um espelho que reflete e materializa o logos, ou como veículo de mensagem, a escrita é freqüentemente depreciada como puro instrumento da língua. Tida como incapaz de representar o vivido, servindo apenas às idéias, já que é o som que faz a entonação e que dá as nuances dos sentimentos, a escrita é muitas vezes desvalorizada em favor da fala.

Os estudos sobre a escrita são marcados por longa tradição que valoriza o pensamento como conteúdo, cuja linhagem é nobre e sagrada, em detrimento da vil materialidade da forma. Qual trabalho das antigas donas de casa, a escrita só aparece quando a arrumação, ou seja, a gramática, é malfeita ou é falha pelas idéias que se lê, ou seja, pelo encadeamento de seu conteúdo.

Quando a escrita é vista como asa para o pensamento, como mero instrumento para suportar idéias, ela se torna invisível, quase inexistente. Contrapondo-se a esta condição, Derrida dirá que “... ao invés de se perguntar apenas pelo conteúdo dos pensamentos, seria preciso também analisar a maneira como os textos são feitos” (citado por Machado, 1998, p. 31).

Mesmo quando a escrita é considerada positivamente por suas relações com a fala, sendo vista como simples representação desta, ainda é degradada por ser morta e rasurável. Todavia, alguns estudiosos chamarão a atenção para o fato de que é apenas a partir da escrita que se fazem as reflexões sobre a linguagem e a fala. Um tal instrumento, dirão estes, cujas funções podem tão 
bem fazer suporte para o discernimento e para a cultura, merece ser tratado em sua especificidade.

As questões acima estão expostas no livro de Ana Maria Netto Machado Presença e implicações da noção de escrita na obra de Jacques Lacan, publicado em 1998. Trata-se de estudo desenvolvido como tese de doutorado em Ciências da Linguagem, defendida pela autora na Universidade de Paris X, em 1996, sob orientação de Michel Arrivé. Logo na orelha de capa tomamos conhecimento de alguns sinais da autora: psicóloga pela Universidade Federal do Rio Grande do Sul, de Porto Alegre, em 1978, onde também concluiu o mestrado anos mais tarde. Desenvolve hoje intensa atividade na clínica psicanalítica e junto a educadores e demais interessados, com o Laboratório de Escrita.

O livro é composto por partes: a primeira parte tem por título "Sobre a noção de escrita”; na segunda parte encontramos "A presença da noção de escrita na obra de Jacques Lacan” e, na terceira, “As implicações da noção de escrita na psicanálise”.

Logo de início a autora procura demonstrar a dificuldade existente na conceituação da escrita. Assim, Ana Maria nos avisa:

... quem se aventure seriamente à procura de um conceito que faça justiça à escrita, cedo vai sentir-se desencorajado, pois será absorvido por longa e polêmica discussão secular, que não tem resultado em nada que possa ser considerado decisivo. (p. 11)

Munida desta convicção produzida por seus estudos, a autora lança mão do termo scriptologia, informando-nos, logo na introdução, de que se trata de um neologismo derivado do termo latino scriptura, que significa escrita. O novo termo anuncia sua ambição: Ana Maria considera que já é o momento de se falar nas condições de um objeto de conhecimento científico que é a escrita. Vale ponderar que o uso deste termo faz costura com o termo scriptor que aparece na citação de Barthes, usada pela mesma autora em seu interessante artigo "Passagem para a autoria - nós entre Barthes, Foucault e Compagnon" ${ }^{1}$. Esta referência nos permite supor que a escrita em que Ana Maria se inspira é aquela que transparece tão bem na fala daquele autor:

... o scriptor moderno nasce ao mesmo tempo que o seu texto; não está de modo algum provido de um ser que precederia ou excederia a sua escrita, não é de modo algum o sujeito de que o seu livro seria o predicado, não existe outro tempo para além da enunciação, e todo o texto é escrito eternamente aqui e agora. É que (ou segue-se que) escrever já não pode designar uma operação de registro, de verificação, de "pintura” (como dizem os Clássicos), mas sim aquilo a que os lingüistas, na seqüência da

1. Artigo publicado em parceria com Miriam Gianella, in Gonçalves, Robson Pereira (org.), Subjetividade e escrita. Santa Maria: Ed. UFSM, 2000. p. 55-81. 
filosofia oxfordiana, chamam um performativo, forma verbal rara ... (Barthes, citado por Machado, 2000)

A scriptologia em que esta scriptora está interessada parece se enriquecer sobremaneira ao considerar a condição em que scripto e scriptor nascem num só tempo. É então aí que mais claramente ela faz atar seu assunto à psicanálise, onde o sujeito do inconsciente é esvanecente e se faz presente em atos falhos, em sintomas, chistes, sonhos.

De modo mais extenso, as idéias acima são desenvolvidas pela autora ao problematizar a noção de escrita ao mesmo tempo em que a propõe como objeto específico de conhecimento. Pouco a pouco, discutindo com lingüistas e historiadores da linguagem sobre a noção de escrita, Ana Maria constitui a fenda que será depois perscrutada nos textos de Lacan, recortando e recuperando o uso dessa noção na obra desse importante psicanalista, para finalmente fazer brotar em conclusão: de um lado, a necessidade da criação de um novo campo de investigação relativo à escrita, ao qual dá o nome de scriptologia; de outro, a autora extrai implicações para a psicanálise, na medida em que deixa claro o caráter visual das marcas inconscientes, sob a materialidade da letra, donde firma, então, o princípio do inconsciente estruturado como escrita, em contraste com o inconsciente estruturado como linguagem, o conhecido aforismo lacaniano.

Qual é a estrutura da escrita, quais as leis gerais de seu funcionamento? Esta é a pergunta que a autora se faz. Para desenvolver seu intento, ela deixa de lado o valor instrumental da escrita para tomá-la como objeto de pesquisa. Para isso, diz a autora, é preciso deslocar a escrita para fora do campo onde é costumeiramente estudada, a lingüística, e desde fora verificar como pode ser concebido o objeto em questão. A psicanálise é o campo de saber que possibilita esse corte.

Uma vez feito esse percurso, a autora dirige sua atenção à obra de Lacan, particularmente para seus Escritos e Seminários (no total de vinte e seis), com a hipótese de que o conceito de escrita fica subsumido ao de fala, mas seu entranhamento e recorrência nos textos do autor é tal que se impõe a hipótese de que isso se deve a uma função de sintoma portador de uma verdade a decifrar, já que não é uma noção clara e permanentemente assumida em suas referências, e que essa verdade não é outra que o inconsciente é estruturado em escrita.

Ora colocada em primeiro plano, ora deslocada para o secundário ou esquecida, a consideração da relação escrita e inconsciente encontrada nos textos de Lacan se impõe já desde Freud em A interpretação dos sonhos (1900). Mais claramente literal do que Lacan, Freud toma os sonhos como uma escrita em rébus. Tal operação requer que se tome as imagens do sonho como uma escrita que deve ser decifrada, como com os hieróglifos. A palavra, unidade mínima para Freud, é tomada então como pura imagem mediante a destituição de significação. Assim separados, 
significado e significante, e também significado e matéria visual, a palavra se faz livre para levar seu leitor à decifração. Com Lacan, onde sempre se lê a prevalência do som, referido à língua e ao significante, o elemento mínimo não será mais a palavra, mas a letra. É sob a consideração da letra que a escrita se articula ao inconsciente, tornando possível a sua circulação nos três registros propostos por Lacan - o real, o simbólico e o imaginário. Para esse autor a escrita é apresentada ora como imagem, portanto, unidade visual e muda, ora como discurso sonoro. Esta condição está presente no funcionamento do sonho, construído de imagens visuais que precisam ser lidas seguindo regras de semelhança e contigüidade.

A letra, muda e visível, é imagem e, portanto, elemento visual que ganha som ao ser lida! E é nessa possibilidade de leitura da imagem destituída de significação que a escrita pode ser tomada como cifrada. É o que fará, por exemplo, com que Eric Porge, outro autor que vem trabalhando as questões da escrita e psicanálise, busque os fatos de escrita nos textos de Fliess, no quadro da acusação de plágio de suas idéias por Freud, detectando o lugar de sujeito do inconsciente ocupado por Fliess naquela polêmica, que se fez com processos jurídicos e manifestações públicas escritas (Porge, Eric. Roubo de idéias? Rio de Janeiro: Companhia de Freud, 1998. p. 140).

O livro de Ana Maria Netto Machado trata de assunto de absoluta atualidade dentro da psicanálise, trazido para nós por uma autora nacional, fenômeno a ser festejado graças, sem dúvida, à aproximação da psicanálise ao esforço de discussão no espaço da universidade, onde a produção de tese sob o regime de pósgraduação joga um importante papel. Em nota de rodapé a autora nos informa que este trabalho de garimpagem das referências à noção de escrita ocupou mais de quinhentas páginas de escrutínio nos textos de Lacan, sendo que apenas algumas passagens constam desta sua publicação, devido a compreensíveis restrições de espaço. Isso nos dá bem a idéia de seu trabalho cuidadoso e exaustivo, sem dúvida de interesse também para outros estudiosos, dentro ou fora da universidade. 